\title{
CONSOLATION - AN UNRECOGNIZED EMOTION
}

\section{EVA WEBER-GUSKAR}

\author{
Georg-August-Universität Göttingen
}

\begin{abstract}
Although consolation is one of the classic religious subjects it plays no role in the current debate about religious emotions. One reason for this neglect could be that this debate is mostly based on classical emotions such as joy and fear, love and hope, and that consolation is not understood as an emotion. This paper tries to show that consolation in fact can and should be seen as an emotion. After naming and refuting some reasons that speak against taking consolation to be an emotion, I will explain how consolation can be positively conceptualized as an emotion within a recent theory of emotions. It will be decisive to see that the experience of consolation can be understood not only hedonistically-qualitatively, but also intentionally. This structural conception allows for a differentiated description of various types of consolation as an emotion, also, in the tradition of William James, of a secular as well as a religious form of consolation.
\end{abstract}

Consolation is one of the classic religious subjects. In Christianity in particular, consolation is regarded as a central experience that is available to the believer through her faith. Consolation is familiar from the Holy Scripture, where God is also identified as the great consoler. One psalm, for instance, says: 'My flesh and my heart may fail, but God is the strength of my heart and my portion forever.' ${ }^{2}$ This fits with a perspective wherein all human life is regarded as in need of consolation

\footnotetext{
${ }^{1}$ Psalm 73.26.

${ }^{2}$ Or in a letter of Paul's to the Thessalonians: 'Now our Lord Jesus Christ himself, and God, even our Father, who hath loved us, and hath given us everlasting consolation and good hope through grace.' 2 Thessalonians 2.16 .
} 
and God, as the Other of everything mundane, as a source of consolation. Christians are also familiar with consolation from Christian practice, in which it is important to provide consolation out of charity, and one can rely on being consolidated by one's neighbour or parish in times of need. Pastoral care, i.e. being there for someone else who is in need, is a muchdiscussed area of theology.

Given this briefly sketched central role of consolation in religion, it is surprising that it plays no role in the lively debate about religious feelings and emotions. ${ }^{3}$ Shouldn't consolation be an example par excellence in this area? Is it not, besides reverence, one of the particularly striking examples of emotional religious experiences? Does its double meaning not show that its role is particularly relevant: as a concrete experience of consolation that someone can offer us in cases of smaller and greater suffering; and as an aspect of the way of life that belief facilitates - i.e. living with the consolation that God provides, given the flawed human existence that everybody somehow experiences as painful?

When wondering why consolation has been neglected in the current debate despite its obvious significance, the following suspicion might arise: consolation is ignored in the debate about religious feelings, because this debate is mostly based on classical emotions such as joy and fear, love and hope. Consolation is not understood as a classical emotion. At the same time, nobody has understood it as a religious feeling sui generis before, in the way that, for instance, Otto took the numinous to be a religious feeling, or Schleiermacher the principal dependency. The reason might be that consolation is understood as a very general phenomenon that is not specifically religious in the same way as the emotional experiences just mentioned are thought to be.

Regardless of what the exact reasons for ignoring consolation might have been, I think that due to its significance, it is an important task to establish consolation as a subject in the debate about religious feelings. Consolation should be introduced to this debate as an emotion that should be investigated in its specifically religious characteristics. One could also address it as a fundamental experience that might help explain what constitutes religious experience and life.

3 There is no individual publication about the topic, and the keyword 'consolation' can also not be found in any overviews. See, e.g., J. Corrigan, The Oxford Handbook of Religion and Emotion (New York: Oxford University Press, 2008). In the following I take 'feeling' as the broad term that includes all experiences that are felt and emotion as a special kind of those, as will be explained later on. 
I am mostly interested in the first type of investigation. In the tradition of William James, I assume that many emotions can have a secular as well as a religious form. ${ }^{4}$ I will not consider the question of whether there are specifically religious emotional experiences that have no secular counterpart in this article.

If consolation is to be introduced into the debate about religious feelings, the first and obvious task is to clarify whether consolation can be taken to be an emotion in a secular understanding at all - prior to discussing its specifically religious characteristics. There is hardly any material available about this question in the relevant disciplines. The philosophy of emotions has neglected the phenomenon, as too have theoretical theology and the neighbouring sciences such as psychology and sociology. Hence I will make this the question of my text: is consolation an emotion?

If you look at recent publications from research about emotions, you will find as little there as on a list of passions from the history of philosophy. ${ }^{5}$ Traditional examples of emotions are joy and sorrow, anger and jealousy, envy and fear. Consolation is never addressed on its own. It is, at least, mentioned in connection with emotions, because consolation is doubtlessly related to sorrow, which is a classical emotion. But can consolation itself be understood as an emotion, despite the impression given by a perusal of the relevant literature?

I would like to answer this question affirmatively: yes, consolation can be taken to be an emotion. Consolation is an emotional phenomenon, and a certain aspect of it was simply ignored in most debates about emotions. I want to describe this aspect here and show why we can - and should - consider consolation as an emotion due to this aspect.

The structure of my paper is as follows: I will first name the reasons that speak against taking consolation to be an emotion and show how these reasons can be refuted. I will then explain how consolation can be positively conceptualized as an emotion within a recent theory of

${ }^{4}$ William James, The Varieties of Religious Experience (Cambridge, Mass.: Harvard University Press 1985), p. 31.

${ }^{5}$ C. Newmark, Pathos - Affekt - Gefühl. Philosophische Theorien der Emotionen zwischen Aristoteles und Kant (Hamburg: Meiner, 2008), pp. $225 \mathrm{ff}$. For a recent 'list of emotions' see, e.g., the table of contents for C. Demmerling, and H. Landweer, Philosophie der Gefühle. Von Achtung bis Zorn (Stuttgart: Metzler, 2007). Nothing can be found either in Robert C. Roberts, Emotions. An Essay in Aid of Moral Psychology (Cambridge: Cambridge University Press, 2003). 
emotions. It will be decisive to see that the experience of consolation can be understood not only hedonistically-qualitatively, but also intentionally. In consolation, one finds something or someone consoling. This structural conception allows for a differentiated description of various types of consolation as an emotion. I will also explain why we can talk about secular as well as religious consolation.

\section{WHY CONSOLATION IS ALLEGEDLY NOT AN EMOTION}

\subsection{Reasons against consolation as an emotion}

I will name three reasons that speak against taking consolation to be an emotion. I have already mentioned the first one in the introduction: consolation is not even considered to be an emotion in any of the common theories of emotions. This is at least made clear in compilations of emotions from Aristotle to Kant. ${ }^{6}$ In contemporary literature, consolation can also neither be found in indices nor chapter headings, and only very seldom en passant in chapters about mourning or similar subjects. ${ }^{7}$ This is true for the philosophical literature as well as - as far as I can see - psychology and neurosciences that have started to intensively investigate feelings since the renaissance of the theory of emotions at the end of the 20th century. ${ }^{8}$

Only in theology, especially in Christian theology, can one find many publications about consolation - but not, as previously mentioned, in theoretical debates about religious feelings; rather in the area of practical theology. This is why one might put forward a second reason against

\footnotetext{
${ }^{6}$ See footnote 1 . The situation in the time 'between Kant and Kenny' is a bit more unclear, Anthony Kenny, Action, Emotion and Will (London: Routledge and Kegan Paul, 1963). In the 19th century, with the differentiation of the sciences, research on emotions was increasingly a subject for psychology. Nietzsche and Freud discussed consolation in their respective critiques of religion without being explicitly interested in the phenomenon as an emotion. In the phenomenology of the early 20th century, consolation is not mentioned.

7 One of the few places in recent monographs on philosophical research about emotions where consolation is mentioned - although not discussed as an emotion in itself - is the analysis of Gustav Mahler's Rückert-Lieder in Martha Nussbaum, Upheavals of Thought. The Intelligence of Emotions (New York: Cambridge University Press, 2001), pp. $281 \mathrm{ff}$.

${ }^{8}$ One example are the popular books by the neurologist Antonio Damasio. Antonio Damasio, Looking for Spinoza. Joy, Sorrow and the Feeling Brain (New York: Harcourt, 2003); Antonio Damasio, Descartes' Error (New York: Grosset/Putnam, 1994).
} 
taking consolation to be an emotion. On closer inspection, these are either texts that are meant to be directly consoling themselves, such as psalms (and their explanations) and songs. Or they are texts about pastoral care. These texts are about consolation, but primarily about how to console someone, and not about what consolation is and specifically not about the question whether consolation is an emotion or not. In this respect, they resemble the few texts from the history of philosophy where consolation is a topic: consoling writings from antiquity such as the ones by Seneca and Boethius. In this sense, consolation can also be found today in a scientific disciple that might be surprising at first: in nursing theory. ${ }^{9}$ On closer inspection, it is of course easy to see why: nursing is an activity where offering consolation plays a huge role. So in these disciplines, consolation takes place, but not as a feeling that one would experience. Consolation is understood as consoling here, it is about offering consolation, about an attitude. ${ }^{10}$

Now one could say that we simply have to distinguish between two perspectives on consolation. On the one hand, we can talk about consolation in the sense of 'offering consolation' or causing consolation. On the other hand, we can talk about consolation in the sense of 'receiving consolation' or actually feeling consolation, so we can talk about a feeling here. Is the state into which a consoling person moves a suffering person, a feeling or, to be more precise, an emotion? ${ }^{11}$ It is not that simple. Given this scenario, one could put forward a third reason against my thesis. The consolation that one receives, one could say, means the end of mourning or similar irksome emotions such as desperation, misfortune, pain. Finding consolation thus would mean that the mourning disappears. Or maybe the mourning does not even have to disappear, and forgetting or repressing it suffices. In any case, consolation here means, it seems, the absence of (certain) emotions rather than the presence of an emotion. One could even go further and say that it is in fact the absence of many or even all emotions. Consolation could be the intermediate state or phase between mourning and new joy about something else. Being

\footnotetext{
${ }^{9}$ See, e.g., F. Gilje, and A.-G. Talseth, 'Mediating Consolation with Suicidal Patients', Nursing Ethics, 14:4 (2007), 546-557.

${ }^{10}$ In medical ethics, the notion of consolation can also be found, but in the sense of offering consolation. Going back to antiquity, it is then understood as a virtue. See W. T. Reich, 'From ancient consolation and negative care to modern empathy and the neurosciences', Theoretical Medicine and Bioethics, 33 (2012), 25-32 (pp. 26f.).

${ }^{11}$ I will explain the difference between feelings and emotions below.
} 
consoled in this sense would be a sigh of relief. A neutral state in which one does not really feel anything at all. Any considerations that merely regard consolation as the end of mourning and other similar emotions point at least indirectly in this direction. ${ }^{12}$

These are the reasons that speak against taking consolation to be an emotion. They confirm a tradition in which it is also not considered as an emotion. But these arguments do not seem very strong to me. I will now show how to reply to them.

\subsection{Why the counter-reasons are not convincing}

The reply to the first reason is simple: referring to tradition is not enough. Just because everyone has always thought so does not mean that they were right. The first of them might not have looked hard enough, and many followed, got used to it or found no cause to question the assumption.

If we do question the assumption, however, there is a good reason for also considering the interpretation of consolation as a consoling activity as misguided, just as neglecting the description of the state that is the aim of consoling is a mistake. This view is at least too limited and obscures the view on an interesting phenomenon. I want to go further here and claim that we cannot really understand what it means to console unless we clarify what happens with the person who receives consolation. Consoling does not tell us what consolation is. We have to understand what consolation is in order to understand what it means to offer consolation - and how to best do that.

I will later show how exactly consolation is to be understood as an emotion (and not just as a certain non-emotional state). For now, I would merely like to point out that the concept of consolation is no exception concerning the fact that it can be both offered and experienced. One can bring joy and also feel joy. One difference might be that one can bring joy in many different ways, but this is more similar to causing it, whereas this is not the case with consoling. When offering consolation, the action itself is more specific and more closely connected with the consolation that is its aim. Hence it is more important for consolation that there is a consoling person. For other emotions, an engaged person is less necessary as a cause. A sunny morning is sufficient for joy. However, even in consolation one might not depend entirely on another person.

\footnotetext{
12 One example is Nussbaum's interpretation of the Rückert-Lieder. See footnote 3.
} 
Even here, the weather or a musical work might play a role. I will come back to this point. For now, I just wanted to show that the complementary structure of giving and receiving also applies to classical emotions. So the fact that consolation has, in most cases, only been discussed in the sense of offering consolation is no reason for insisting that consolation can only be an action and not a feeling.

Now to the third point. How is the state that consoling aims to bring about, how is the consolation that someone who is desperate seeks, to be understood? Is it a non-emotional, neutral state as suggested above? Is it the state 'after' mourning, desperation and the like? Does finding consolation, finishing mourning, or leaving it behind, mean that one has escaped the grasp of emotion? That does not seem plausible to me. I will explain this with the analysis of a rather general example. I will then substantiate my thesis with the basis of a theory of emotions. ${ }^{13}$

Imagine a classical situation where consolation is needed. Someone loses someone who is close to her, for instance in a car accident. She is desperate, angry at the guilty driver or at fate, and, most of all, very sad about her loss. After the worst few days that she mostly spends in shock, she is in need of consolation. How is this wish for consolation to be understood? There are at least two possibilities. Does this person want to overcome her mourning? Does she want the mourning to simply stop so she can be happy again, like before? Or does she want to be able to deal with the mourning, i.e. with her loss - which means, does she want to change the state of suffering, but not simply get rid of it? The second answer seems right to me. Mourning contains an appreciation of what was lost, or in this example, of who died. Simply getting rid of the mourning would then mean to somehow deny the appreciation. This is surely something the mourning person (at least usually) does not want to do. Hence the wish for consolation should not be directly understood as the wish for the mourning to end. It is rather plausible to understand the desire for consolation as the desire for an altered emotional state, and not for the end of negative emotions. If we think this is an understandable desire, then consolation has to be seen as an emotional state on its own. Someone who is desiring consolation wants to feel consolation.

13 The main thought of the following arguments about consolation as an emotion I have already presented - in a shorter version - in Eva Weber-Guskar, 'Religious Emotions as Experiences of Transcendency? The Example of Consolation', in Theologie der Gefühle, eds. R. Barth and C. Zarnow (Berlin/New York: Walter de Gruyter, forthcoming). 
Some might find this view unconvincing and argue that consolation is an emotionally neutral state by presenting a different example. If a child hurts his knee while playing, the child runs to his father crying, because he wants to be consoled. This is easily done by the father by putting a band-aid on the wound, saying a few nice words and offering a chocolate. The child stops crying and runs back to the other children in order to continue playing. Here, one might think, being consoled indeed means getting rid of pain and being happy again.

However, strictly speaking, a case like this needs to be described differently. In this case, too, finding consolation does not simply mean getting rid of the pain. The pain in the child's knee might last all afternoon and only stop in the evening. Long before that, he has already played with the others again. The attention and friendly words of the father, the fact that he hugged the child, enabled the child to bear the pain and to find it not terrible enough to stop him from playing. Consolation consists in not completely erasing negative emotions in this case, too, but in changing them in a way so one can deal with them.

It does not matter that in one case, with the adult, the pain is mental and in the other case physical. Not only does the child's knee hurt, he is also shocked by the constraint in playing that the pain imposes, he is sad that he can no longer run like before. The physical pain is, as it were, accompanied by mental pain. The pain is lessened by making it clear to the child: you can still play, you just cannot run like before and not as easily.

Even if one is not convinced by this example, one could just regard it as a different variant of consoling and come back to the first example and show that there is at least also a variant of consoling that leads to consolation in the sense suggested by me: to an emotional state on its own. If you suddenly lose your partner in a car accident, it is just impossible to simply get over his death and to be as happy as before. This is not only because of what one wants - as I said above - but because of what is possible for a person in her emotional integrity. The exact consequences of such a denial of appreciation would be worth an investigation. But I would even go further in cases of dramatic losses and the attempt to get rid of the corresponding mourning: not only is the question how people want to express their appreciation for someone or something who was lost at stake here, but also their ability to evaluate or to be aware of what is valuable (and to what extent) to them. For this quick dissolution of mourning would mean to suddenly erase a very important point of 
orientation in one's personal value-landscape. It is possible, however, even after such strokes of fate, to organize oneself anew inside, to be a person who can continue to live with the loss. ${ }^{14}$ And this means to find consolation. Consolation is not the dissolution of mourning, but a change of the emotional surroundings of mourning and hence an emotion on its own (which only depends on mourning or a misfortune).$^{15}$

These are the arguments against the first reasons why consolation should not be considered as an emotion. Now I want to explain in more detail why consolation can be described as a type of emotion, based on a theory of emotions.

\section{CONSOLATION AS AN EMOTION}

\subsection{Emotions as a type of feeling}

In order to show more precisely why consolation is an emotion, a very brief explanation of what emotions are is required - beyond the evidence that a simple comparison with the examples of joy, anger, etc., might provide.

By emotion, I mean - drawing on a well-known stance in contemporary philosophical discussion - a certain type of intentional state, namely, a state whose reference to the world is affective. Emotions exhibit a qualitative experiential dimension. ${ }^{16}$ This dimension is what distinguishes emotions from other intentional states such as beliefs and desires. They differ from other affective states by their specific type of intentionality beyond the affective dimension. Bodily sensations, such as an itch, are restricted to the limits of the body. Moods like melancholia

${ }^{14}$ E.g., the theologian Langenhorst also writes in this sense: 'Offering consolation, that is enabling (encouraging, accompanying, facilitating or stimulating) the mourning person to take further steps with better hope towards the future her way through life with her mourning - be it in lament, rebellion or acceptance.' G. Langenhorst, Trösten lernen? Profil, Geschichte und Praxis von Trost als diakonischer Lehr- und Lernprozeß (Ostfildern: Schwabenverlag, 2000), p. 18.

15 This new constellation might, in the end, also lead to completely overcoming mourning, but first it facilitates a life with a certain variant of mourning.

${ }^{16}$ An overview of the recent research in this field is, e.g.,: Sabine Döring, 'Einleitung, in Sabine Döring, ed., Philosophie der Gefühle (Frankfurt am Main: Suhrkamp, 2009), pp. 12-65. And: Peter Goldie, ed., Oxford Handbook of the Philosophy of Emotion (Oxford: Oxford University Press, 2010). My own approach can be found in Eva Weber-Guskar, Die Klarheit der Gefühle. Was es heißt, Emotionen zu verstehen (Berlin/ New York: Walter de Gruyter, 2009), especially Chapter 1. 
or euphoria are less precise concerning their reference to the world. If you are sad, you can point out the reason or at least a trigger. If you are melancholic, everything appears in a dim light, and you do not know why exactly. The core definition of emotions should then be: emotions are qualitatively experienced attitudes in which we (kind of) perceive something in the world as, in a certain way, valuable for us. If I am sad, this means that I understand something in the world, in an irksome feeling, as - in some way - bad for me. To be more precise: I mostly understand it as a loss, as something that takes something important out of my life. Something presses me to the ground, makes my life difficult. Getting up is already difficult, and maybe every step is difficult throughout the whole day.

These formulations, starting from the aspect of intentionality, must not be misunderstood concerning the question of whether emotions can only be taken seriously as epistemological categories. In some respects, emotions are often compared with perceptions, but are not equated with them. It is part of an emotion to be affected by something and to stand in a relationship to something other in the world. We could say: they are moments of a way of being involved in the world. ${ }^{17}$ Being involved in the world goes far beyond propositional perception.

Besides this core definition, there are further aspects belonging to the explanation of emotions. I want to mention two more: firstly, very often, emotions contain motivations to act - or are at least connected to them. In the case of mourning, this would be to withdraw from the world, or at least from a happy party. Secondly, emotions are most often shown in a bodily expression. We all know what a sad face looks like. This is not only one of the facial expressions that are universally recognized, as Ekman has shown. ${ }^{18}$ It seems to be a gestalt psychological form that we think we recognize in other beings, even in unconscious beings, or at least we read it into them. Think of sad dog eyes or the droopy twigs of a weeping willow.

If we take these features to be basic for an emotion, is the state into which the consoling person puts a suffering person then to be described

${ }^{17}$ The formulations about feelings or 'feeling involved in something' can also be found, as a quote by Agnes Heller and then further developed in H. Steinfath, Orientierung am Guten: praktisches Überlegen und die Konstitution von Personen (Frankfurt am Main: Suhrkamp, 2001), p. 117.

18 See, e.g., P. Ekman, Gefühle lesen. Wie Sie Emotionen erkennen und richtig interpretieren (Heidelberg: Spektrum, 2004). 
as an emotion? With the help of the three main features that I mentioned I will show that this can indeed be done.

\subsection{Consolation as a specific type of emotion}

\section{Phenomenality}

By contrasting the state of being consoled with the state of being relieved and its phenomenal dimension, we can illustrate that consolation has a phenomenality. Consolation and relief resemble each other by having a similar situation as their precondition - namely mourning, desperation, pain or another misfortune and a movement away from it. But apart from this circumstance, consolation and relief differ. Relief is felt as a complete relaxation, a feeling of being liberated and, literally, being light - like 'taking a load of one's mind'. It occurs and is appropriate if you learn, for instance, that the child that you thought was badly hurt in the bus accident was the only child who survived unharmed. Consolation, however, is felt as ceasing pressure and similar sensations, but only as a relaxation up to a certain point. It is not a complete relaxation. The feeling can be associated with a warm, dark place, where one can feel at home - but not with a bright place that is part of the joy that can follow after a complete relief. Consolation is, as the example illustrates, not the end of mourning and misfortune, but a change of these dark feelings.

\section{Motivation to act}

Someone who has found consolation usually exhibits certain motivations to act. They differ from those of someone who is (still) mourning and those who have completely finished mourning. We can find many explanations of this in, for example, Seneca. In a long letter, the stoic philosopher gives recommendations to a mother, Marcia, who is mourning over the death of her son. ${ }^{19}$ This seems to be a behaviour that fits with consolation as an altered form of mourning. If you are deeply in mourning, you probably do not want to let go of the thought of the person, but in a problematic sense, namely not completely accepting her death. For instance, you might not want her room to be touched or used by anyone. You stick to rituals you had together, but that no longer make any sense now. The other extreme would be to completely leave the

${ }^{19}$ Seneca, 'Trostschrift an Marcia', in Vom glückseligen Leben, H. Schmidt (Stuttgart: Kröner, 1956), pp. 119-158. 
mourning behind and to not care at all what happens to the room and the rituals. In such a case, finding consolation means to be able to honour and keep memories, but to still continue one's life in a new way. This could be manifested by keeping the furniture in the room, but letting someone who needs it, use it. You can only do this (without emotional distortions) if the mourning has changed, if you have found consolation, i.e. a way to regard the world as still worth living, despite the loss.

\section{Intentionality}

In the sense of the above mentioned core definition, the intentionality of consolation can be formulated as follows: feeling consolation means to experience something in a pleasant way that lowers one's pain, and hence to experience it as valuable for one's life and well-being. We can also illustrate the triad of reference to the world in individual aspects as it has become common since Bennett Helm. ${ }^{20}$ We can talk about an object of consolation, which is who or what is consoling; a formal object, which is the object's property to lessen the pain; and a focus, which is one's own pain or misfortune. While the formal object - as the definiens of the type of emotion - is always the same, focus and object of consolation can differ. Based on these two variables, I will now outline the varieties in which consolation can take place.

\section{VARIETIES OF CONSOLATION}

\subsection{Concrete misfortune or suffering from the whole world}

We can, in principle, distinguish between two different possibilities concerning the focus of consolation. It is either about a concrete, personal misfortune, usually a certain event (or several, as with Job in the bible; a prime example of dealing with unbearable suffering). Or it is about a more abstract, existential misfortune - suffering from the world, from how it is, from human life as such, of which suffering, ignorance and transience are part. These two meanings can also be found in the few canonical texts on consolation in ancient philosophy. ${ }^{21}$ For the first case,

${ }^{20}$ See, e.g., B. Helm, 'Felt Evaluations. A Theory of Pleasures and Pains', American Philosophical Quarterly, 39, (2002), 13-30 (p. 15).

${ }^{21}$ For one of the few philosophical treatments of consolation in modernity, especially existential consolation, see: Paul Ricoeur, 'On Consolation', in The Religious Significance of Atheism, Alasdair MacIntyre and Paul Ricoeur, eds. (New York: Columbia University 
the writings on consolation by Seneca are exemplary. ${ }^{22}$ Boethius' piece about consolation is an example for the second case. ${ }^{23}$ It also begins with a concrete misfortune - the situation of being accused of conspiracy, being incarcerated and sentenced to death - but his thoughts expand to the situation of human beings in the world in general. Both variants can also be found in theology. ${ }^{24}$ Traditionally, religion is interested in providing humans with consolation about their existence in general. Currently, the subject of consolation increasingly centres around individual misfortune, although only in the sub-discipline of practical theology or its branch of pastoral care. ${ }^{25}$ In what follows, I will talk about varieties of consolation, depending on their intentionality, in the first sense, i.e. concerning concrete misfortune.

\subsection{Offellow human beings, art or God}

The object of consolation, i.e. what a suffering person in her emotion takes to be an alleviating influence, can be manifold. How, with the help of who or what, can she find consolation?

A first thought is: with the help of someone else. When we are sad or desperate we often wish for someone on our side and call for someone, if possible. We want to talk about our suffering, to share it, we do not want to be alone (I will say more about this consoling and being consoled between two persons below).

We can also find consolation in other, not directly human experiences. Art can also offer consolation. I mean art in a passive as well as active sense here, i.e. as the reception and exercise of art. In general, both can

Press, 1969), pp. 81-98. The idea of consolation as something dialogical can also be found there (p. 90).

${ }^{22}$ See Seneca, 'Trostschrift an Marcia', pp. 119-158. Other, less well-known ancient writers are also mentioned in H.-T. Johann, Trauer und Trost. Eine quellen- und strukturanalytische Untersuchung der philosophischen Trostschriften über den Tod (Munich: Fink, 1968).

${ }^{23}$ Boethius, De consolatione philosophiae - Trost der Philosophie. Lateinisch- deutsch (Düsseldorf et al.: Artemis und Winkler, 1998).

${ }^{24}$ Two theological studies offer an overview and some interesting analyses: T. Weyhofen, Trost: Modelle des religiösen und philosophischen Trostes und ihre Beurteilung durch die Religionskritik (Frankfurt am Main: Peter Lang, 1983); G. Langenhorst, Trösten lernen? Profil, Geschichte und Praxis von Trost als diakonischer Lehr- und Lernprozeß (Ostfildern, Schwabenverlag, 2000).

${ }^{25}$ See, e.g., S. Rolf, Vom Sinn zum Trost: Überlegungen zur Seelsorge im Horizont einer relationalen Ontologie (Münster: Lit, 2003). 
be called engaging with art. This thought, although familiar as a roughly understood topos (as one can see, for example, in interpretations of music $)^{26}$ could be explained with a theory of art that understands art as a process of self-understanding. ${ }^{27}$ Engaging with art would then mean engaging with oneself, which would mean, in mourning, addressing this mourning or, more generally, addressing oneself as a being capable of suffering and mourning.

These first two intentional areas of consolation show that the analogy with perception in the theory of emotions must not be understood too narrowly, as I previously warned. To experience something as consoling does not so much mean to realize it as being consoling, but rather that this sets a process into motion in oneself. This process is the transformation of mourning in which finding consolation consists. Finding consolation by the help of another person has much to do with really meeting the other person. Finding consolation in art either has something to do with becoming aware of oneself in the new situation, and gradually restructuring oneself, or it has something to do with a practice, such as playing the piano. If you pay less attention to the content of the music, but rather see music as an engagement with forms, one can see the move here to saying that certain ordered activities can provide consolation. How? One thought is that one has 'fallen out of the world' or that one has, more poetically speaking, 'become lost for the world', as expressed in the famous Mahler song based on the Rückert poems. Besides practicing art, maintaining rituals therefore also belongs to this type of consoling activities.

This insight also contains a link to religious consolation. Religion provides many consoling rituals, such as prayer, the rosary, mass, singing, etc. Even dividing the year into bank holidays can, as a great rhythm, contribute to consolation. ${ }^{28}$ But consolation can also be experienced by

${ }^{26}$ Franz Schubert's Streichquintett in C-Dur, D 956, for instance, counts as a prime example of a work about mourning and consolation. Mourning and consolation are exemplarily represented in this musical work. The sounds of consolation are not entirely different from those of mourning, but resonate in them.

${ }^{27}$ Contemporary proponents of this view are, e.g., G. Bertram, . 'Was die Kunst der Philosophie zu denken gibt', Allgemeine Zeitschrift für Philosophie, 34:1 (2009), 79-98. And D.M. Feige, Kunst als Selbstverständigung (Paderborn: Mentis, 2012).

${ }^{28}$ For the meaning of 'rhythm' as a religious experience, cf. H. Wettstein, The Significance of Religious Experience (New York: Oxford University Press, 2012), pp. 45f. 
the concrete contents of faith. ${ }^{29}$ The most prominent example is belief in life after death. Generally, the belief in a benevolent God surely also plays a central role here. Of course, then one has to face the theodicy question. Why does God permit suffering to happen? Someone who has an answer to this can find consolation in God. It would be a further question to wonder if, from this religious perspective, any consolation is, in the end, given by God, but manifested differently (in a concrete person or in art (see below)). This question, however, is not central for the basic idea of consolation.

A classic topos about what can provide consolation is, fourth, philosophizing. This is at least the ancient conception of philosophy and best-known from the formulations of the late ancient philosopher Boethius. ${ }^{30}$ Of course we have to keep his conception of philosophy in mind. For him, philosophy is not only thinking about questions, not only wanting to understand and realize. Primarily, philosophy means thinking about what is a good life and trying to live accordingly. Boethius' view is also strongly influenced by religious ideas. With philosophy as a process of thinking and realization, we allegedly not only arrive at just any insights, but at a specific one: the world is basically fine and created out of God's eternal council. So Boethius' idea of philosophy as consolation can, in the end, be understood as a variant of religious consolation. In this case, not due to rituals, but due to a specific content of belief, i.e. that the world is basically, if we properly look at it and understand it, well-designed by God.

At precisely this point, a critique of religion can turn into a critique of consolation, as in Nietzsche's writings in particular. ${ }^{31}$ If you do not agree with the belief in a world well-designed by God (the best of all possible worlds, as Leibniz wrote), then a consolation that is based on

${ }^{29}$ For various forms of religious consolation, see T. Weyhofen, Trost: Modelle des religiösen und philosophischen Trostes und ihre Beurteilung durch die Religionskritik (Frankfurt am Main: Peter Lang, 1983), pp. 249f.

${ }^{30}$ Boethius, De consolatione philosophiae. For the following summary of the main thoughts of Boethius' works, I refer to T. Weyhofen, Trost: Modelle des religiösen und philosophischen Trostes und ihre Beurteilung durch die Religionskritik, pp. $124 \mathrm{ff}$.

31 'We have every right to call Christianity in particular a large treasure-trove of the most ingenious means of consolation, so much to refresh, soothe and narcotize is piled up inside it.' Friedrich Nietzsche, On the Genealogy of Morals, translated by Carol Diethe (Cambridge: Cambridge University Press, 1994), p. 69. 
such a belief must be wrong. ${ }^{32}$ The question about the truth of matters of faith is one thing and should be treated with care. It is another thing whether the emotion of consolation can be criticized. I will only address this question, because it belongs to the general explanation of consolation (whereas the first point only concerns religious consolation).

Following from what I have said so far, consolation would have to be criticized just like any other emotion. Emotions are not true or false, but appropriate or inappropriate, and can only be criticized in this respect. An emotion can be inappropriate because it is based on beliefs that are simply false. An example would be being consoled by the thought that there is an afterlife, when in fact there is no such thing. By now, of course, Christian ideas are not necessarily taken that literally. But that is a topic in itself. A secular deception would be if you feel consoled after a conversation with someone and later learn that this person has made fun of you and your mourning. He only pretended what he said in order to get his share of the inheritance.

It is more difficult to decide whether an emotional reaction to a state of affairs that was correctly understood is appropriate or not. There are individual differences, of course. People do not all perceive the same thing as consoling. The presence of the best friend might be consoling for some people, but not for others. But since one would immediately find this to be obviously consoling, someone who feels differently has to explain why. Besides the general rules for which emotion we find appropriate in which situations, there are always individual rules that stem from the individual character and story of life. Perhaps the connection to the best friend is so strong that her presence increases the mourning, because the sensation is, as it were, doubled by the friend's sympathy. This person rather needs a stranger. One person can also find a musical work consoling, whereas someone else thinks that this music is kitsch and regards consolation based on the music as inappropriate.

${ }^{32}$ A classic criticism of religion can also be found in Sigmund Freud. Similarly to Nietzsche, he criticized religion for its promise of consolation: 'I disagree with you when you conclude that man cannot go without the consolation of religious illusion, that he could not bear the burden of life, the gruesome reality. Indeed, not the man who you have infused with the sweet - or bitter-sweet - poison from his childhood on. But the other one, who grew up sober? Maybe he who is not suffering from the neurosis also does not need an intoxication in order to numb it.' (Translation M.W.) Sigmund Freud, 'Die Zukunft einer Illusion', in Studienausgabe (Frankfurt am Main: Fischer, 1927), IX, pp. 137-189 (p. 182). 
In this case, the character and history of the mourning person, her experience with music and her associations will also matter. The criterion for appropriateness is coherence within the person herself. This idea can be explained in more detail by drawing on Bennet Helm and his thesis of a structured pattern that connects the emotions, if they refer to the same focus. If you love someone, you are happy when he feels good, and you are mourning if you lose him, for example. The emotions are connected in a structured pattern, since it would be incomprehensible if someone - without any further explanation - would be happy about seeing a beloved person again, but not mourn at all over his loss. ${ }^{33}$ This pattern and its rules provide a reference point for considering a specific emotion - in the context of a person's other emotions - to be appropriate or inappropriate. If you find the musical piece consoling you cannot find it scary or trivial the next day, all else being equal, without your emotion becoming incomprehensible or open to criticism.

This clarification about the criticizability of emotions is important here, because it allows us to contour the difference between consolation in the original sense and different ways of dealing with negative emotions. Consolation, as I have described it, as an emotion, needs to be distinguished from the results of being distracted or being 'on the rebound'. (Especially in German both phenomena are easily mixed up because 'Vertröstung' seems to be the same as 'Trost'.) The latter both mean to ignore the suffering, to replace the loss by something else or to not regard it as severe. To distract someone often means to postpone something to a later point of time. But this already implies that there is no real hope that this will ever be fulfilled. One is on the rebound and knows that one has lost already. Some people try to be on the rebound over a loss by quickly replacing a partner with a new one, or just by getting drunk and washing the worries away. But all of these are ways of not taking a suffering or mourning seriously, of not dealing with it and not integrating it into a life that needs to be reorganized. In the end, they are a form of denying suffering, a self-deception. This is precisely how consolation, as I describe it here, is not to be understood. They are phenomena from the same area - engaging with mourning - but not the same phenomena.

${ }^{33} \mathrm{Helm}$ has argued for this in several places, e.g. B.W. Helm, 'Emotions as Evaluative Feelings', Emotion Review, 1:3 (2009), 248-255 (pp. 251f.). 
All of the transformations mentioned so far (and possibly more varieties of it) would have to be fleshed out in more detail, which would be a project on its own. In this paper, which sheds new light on a research topic, I only wanted to provide at least a certain overview to show how consolation can be understood as an emotion.

To conclude, I want to talk a little more about the variant of consolation that was mentioned first, in order to elaborate my thesis of consolation as an emotion a bit further. How can people offer consolation to each other? Which emotional constitution exactly is the aim here?

\subsection{What methods of consoling tell us about consolation}

We have to distinguish between at least three methods. They might not (maybe never) occur in their pure form, but as a mixture: listening, buoying, presence or being there for someone. ${ }^{34}$

The method of listening is the easiest to explain and also to practically learn. You listen carefully to what the suffering is of someone who is looking for consolation. Talking can already be partly relieving. At least it opens the space for two people to engage with each other such that consolation can be given and received.

But what are the right words that could follow? Especially with severe misfortunes, many close people are very afraid of not finding the right words and so rather say nothing. But it is more important, says someone who is affected by this situation, to try it. ${ }^{35}$ If you say something, there are various possibilities. Although it depends on the individual in question, some work better than others. The ones that work can, again, inform us about the appropriateness of my thesis that consolation is an emotion,

34 The following considerations have to be understood as an independent, more general phenomenological analysis, based on the reports by people who are affected by suffering as well as the consoling side that can be found in texts on pastoral care and others. There is very little empirical-scientific material on this. A small study from nursing theory is helpful. F. Gilje and A.-G. Talseth, 'Mediating Consolation with Suicidal Patients', Nursing Ethics, 14:4 (2007), 546-557. It describes how consolation arises between two people. One thing that is emphasized, among others, is listening and being present. Also mentioned is a dialogue and opening of two sides, so that you, as it were, meet in consolation. In this study, 10 of 18 consoling persons were priests.

${ }^{35}$ This is, for instance, what the author Max Dorner, who is suffering from multiple sclerosis, says in a feature of Bayerischer Rundfunk. Available at: <http://www.br.de/ radio/bayern2/sendungen/land-und-leute/troesten-und-getroestetwerden-dorner-108. html $>$ [accessed 29/08/2014]. 
which means a change of mourning - an emotion that builds upon mourning.

What does not help at all in this sense is talking about a replacement as if a true loss could simply be replaced (this might be possible with small misfortunes, but not with major ones where consolation, in an emphatic sense, is required). Not very helpful is relativizing, i.e. saying that things are not too bad. What helps is: first and foremost, to acknowledge the misfortune as what it is. Then one can point out how life can be continued despite or with this loss, or whatever kind of misfortune has happened. No concrete suggestions are immediately needed. Saying that others have suffered the same can also help, because it shows that you are not the only one who has to deal with such a difficult situation. Subsequently, it is important to (re-)direct the focus on the good things the suffering person still has in her life - not in order to counterbalance the misfortune, but to show what her future life, her concerns, her reason to live, to act and to feel joy, can be based on, despite the misfortune. Consolation does not require a negation or overcoming of loss, but a different adjustment of oneself. An adjustment in which the misfortune is no longer determining one's emotional state, but only one element among several important aspects of life.

Of course it is unbelievably difficult when the most important thing in life has vanished - when a simple shifting of life's focus is not possible, and there is a gap. The only thing that helps now is building up a new perspective from scratch. For this task, it might be important to have someone else. Someone else can (despite the initial empathy in which the perspective of the misfortune is adopted) help to widen the perspective or to 'lift the eyes', as it says in the famous consolation psalm $121,{ }^{36}$ beyond the perspective that one had before and that has meant everything until now. It might be helpful that another person shows us that there are also other ways of being in the world. For ourselves, this means in such a situation: that there is a new way of being in the world, despite the loss. This does not mean adopting the perspective of someone else, but finding one for ourselves. In other (equally metaphorical) words this means that one has to find a new emotional home. ${ }^{37}$

36 'I will lift up my eyes unto the hills, from whence cometh my help. My help cometh from the LORD, which made heaven and earth.'

37 The notion of 'being at home' for the description of consolation is central for the study mentioned above by Gilje and Talseth. 
If this idea is so particularly important for consolation, i.e. the capacity to look beyond the borders of one's own 'world' that is constituted by the emotional dispositions, which, again, are attached to a (or a few) focal point(s) that determine the direction of the whole - then we can also understand why it is not so decisive, as stated before, what is being said. It is important that another person is with you, i.e. primarily is present, a fellow human being, as mentioned under the third point of the 'method'. By being present, someone 'means' more than 'saying': you are not alone, you can find a way to live in the world again, despite the misfortune, because others are also able to do it in their own way (of course, not every way is possible for just anyone - and is surely also not the only way).

In this explanation of consolation, which simply starts with interpersonal consoling, we can see that secular and religious consolation are not as different as we might think at first sight. It is obviously decisive for the consolation that consists in being consoled by another person that there is something 'beyond our self'. On a small scale, this is another person. On a bigger scale, this is maybe the transcendent: something that is beyond our visible and perceptible world. At least this fits with Levinas, who calls the Other the transcendent. ${ }^{38}$ This could be a bridge between a religious and a secular understanding of consolation. In the emotion of consolation, I experience the presence of another existence as alleviating my suffering. This experience is the process of transforming suffering and mourning into an emotional state that frees my life from the stagnation caused by the experience of suffering, and it provides new movement for my life. What this 'other existence' is can be interpreted differently. One obvious possibility would be another person, a fellow human being, the neighbour.

\section{CONCLUSION}

I hope to have shown in the three steps that consolation can indeed be understood as an emotion. The objections mentioned at the start could be refuted, the phenomenon could be reconstructed after the model of a philosophical theory of emotions, and the varieties of consolation could

${ }^{38}$ This would have to be shown in more detail in his writings: Emmanuel Levinas, Totalité et infini. Essai sur l'exteritorité (The Hague, 1961); Emmanuel Levinas, Autrement qu'être ou au-delà de l'essence (The Hague, 1974). 
be secularly and religiously described in their similarities and differences, providing us with an insightful account. Only if we regard consolation not just as the end of something - i.e. of mourning, desperation and the like - but as a genuine state in itself, can we describe the phenomenon in detail and compare it with different varieties, based on the analysis of the types of reference that occur in it. I hope to have provided an impulse for how consolation can be accounted for in the debate about religious feelings and further examined with interesting results. 